\title{
BRICS: Information Asymmetry in Primary Equity Markets
}

\author{
Tanvi Pruthi' ${ }^{1}$, Saroj Koul ${ }^{2}$ \\ ${ }^{1}$ Geeta Institute of Law, Haryana, India \\ ${ }^{2}$ Jindal Global Business School, Haryana, India \\ Email: tanvigil@geeta.edu.in, skoul@jgu.edu.in
}

How to cite this paper: Pruthi, T. and Koul, S. (2019) BRICS: Information Asymmetry in Primary Equity Markets. Theoretical Economics Letters, 9, 1817-1833. https://doi.org/10.4236/tel.2019.96116

Received: May 28, 2019

Accepted: August 11, 2019

Published: August 14, 2019

Copyright (c) 2019 by author(s) and Scientific Research Publishing Inc. This work is licensed under the Creative Commons Attribution International License (CC BY 4.0).

http://creativecommons.org/licenses/by/4.0/

\begin{abstract}
Robust equity markets promote economic development. Most developed nations have stringent disclosure requirements for companies that intend to raise capital through stock markets; which further helps in strengthening equity capital markets. Following their footsteps, developing countries like BRICS have enacted such regulations. This research is doctrinal where a systematic approach is undertaken to examine the current legal framework about asymmetric information in the equity capital markets of BRICS countries. This research shall act as a testament to the claims of securities regulators in BRICS countries who want to create a safe environment for investors by promoting transparency. This research aspires at contributing to the existing literature on primary equity capital markets by identifying such laws that help in reducing information problem between market participants. While this is regulatory driven analysis; additional research could be carried out to check the implementation of these laws in BRICS countries.
\end{abstract}

\section{Keywords}

Information Asymmetry, Equity Markets, Disclosure, BRICS, Economic Growth

\section{Introduction}

The Primary market acts as a springboard for both issuers of securities and investors. Through primary markets, firms (and governments) raise the capital that comprises an integral part of their financing needs. Information asymmetry is indispensable in capital markets scenario. Howbeit, its reduction could be achieved through disclosures. Therefore, disclosures become essential, as they benefit both companies issuing shares and the investors. Especially in the primary markets, information disclosure becomes all the more critical for the 
protection of investors so that no charade company can scam them. While voluntary disclosures remain useful in reducing information asymmetry, they are not substituted for the mandatory disclosures while informing the informational anomalies. Following these lines, securities regulators around the world, including the five specific high profile emerging market economies of the world namely Brazil, Russia, India, China and South Africa (BRICS), have adopted stringent disclosures norms to enhance transparency. This transparency is aimed at strengthening the stock markets of these nations to promote economic growth.

\section{Literature Review}

The relation between equity markets and economic growth has always been a field of research, explored by scholars in abundance. Levine [1] has established a "strong and significant relationship between stock market development and economic growth". BRICS economies, a close association of five specific high profile emerging market economies of the world [2] have proven quite resilient to global shocks [3]. Thus, with their growth stories unfolding, it becomes pertinent to analyze such factors that are significant threats for facilitating robust equity markets in these countries and the legal framework about it: one such being, information asymmetry.

The concept of asymmetric information first introduced [4] with the example of the Automobile Industry, contends that the standard of goods is evaluated by the buyers using some market statistics whereas the seller who possesses extensive information of a particular item [4] has a favourable position. As such, the common knowledge of the buyer works to his inherent disadvantage. It only encourages the seller to sell the goods which are significantly below the average market standards. The unintended consequence of it would be a reduction in market size. According to [5], specific markets possess the characteristics of dissimilarity of information between buyers and sellers. Financial markets exhibit lemons problem transparently because capital borrowers have a better knowledge of the projects that they are going to pursue through that money. They also assert that lenders have difficulty in understanding the real nature of borrowers, but the presence of moral hazard as recommended by [6] complicates the direct transfer of information between buyers and sellers.

Jan et al. [7] while assessing the application of [4] theory of information asymmetry in other market argues that this information disparity between market participants give rise to the "phenomenon of the lemon market". Higson [8] further states that the selling of inferior quality products in the market leads to the "so-called lemon problem". From the illustration of the car market, they say, that lemon is a derogatory term used for inferior quality products, such as the poor quality second-hand car [4]. Scholars have suggested several solutions to the lemons problem. Kreps [9] suggests that ideal contracts give an advantage to investors for sufficient disclosure of "private information" by firms. Healy and Palepu [10], provide another proposed solution to the information asymmetry 
problem. They postulate that regulations should be imposed on managers so that they "fully disclose their private information". They further suggest that "information intermediaries" (such as financial analysts or rating agencies) could play a key role in resolving the lemon problem [9].

However, several researchers argue [11] information asymmetry "cannot be eliminated and can only be reduced". Thus adequate legal framework is essential in checking the illegal use of information asymmetry and for reducing the same. Paredes [12] rightly puts it that "fundamental challenge while promoting economic growth in a developing country is designing the right legal system for it". Klonowski [13] while assessing the private equity market of BRIC countries has opined that a sound "legal infrastructure" is imperative for their development. Similarly, studies on "Securities Laws" argue their importance for stock market development and propose that "Securities Laws" simplify private contracting instead of working as public regulatory enforcement [14].

Scholars have analyzed and concluded that disclosure norms not just reduce information asymmetry but also have positive effects on stock markets. A positive relationship between "stock market disclosure system" and "market development" was proved by examining memberships at the World Federation of Exchanges [15]. Also, [16] [17] have proved that "quality disclosures" lead to mitigating information asymmetry, and that voluntary disclosures are advantageous for firms as it reduces transaction costs and circulation of negative information reduces the chances of legal liability [18]. Voluntary disclosures by firms as proposed [19] not just reduces information asymmetry but also assist in reducing transaction costs and cost of capital. Same way, [20] stipulate "voluntary disclosure enhances a firm's governance attributes in diminishing stock market asymmetry" and further imply that a composite "informational-decisional system", corporate governance mechanism can be conducive to in lessening of informational asymmetry.

While, the objective of corporate governance mechanism [21], "is to reduce the expectation gap between investors" and "to reduce the effects of information asymmetry" a robust disclosure regime is "a pivotal feature of market-based monitoring of corporate conduct" and it can help in "maintaining confidence in capital markets" [22]. Thus after several years of study [23], corporate governance and disclosures norms were found to be advantageous for companies, and disclosure rules and regulations for investors and markets considered as a useful tool to encourage good governance practices [23]. The markets function well when investors make decisions in the market based on the information they receive from reporting.

"BRICS grouping is a symbol of the changing world economy" [24], several writers forecast the "potential economic growth for the next thirty years assumed to make BRICS countries the next world economic and financial power" and that their markets "continue to represent increase interest of financial investors" [25]. While examining Brazilian Capital Markets Laws, drafted quite similar to 
the United States Securities Act, 1933 in terms of the philosophy of disclosure, [26] calls it as a tool for protecting investors. Again, while assessing the regulatory structure of the Chinese securities market; [27] states that "China Securities Regulatory Commission" has the authority (power) to "supervise and inspect information disclosure of securities" and to monitor continuous disclosure for investor protection. Similarly, [28] contends that the Federal Commission on Securities Market of Russia, initially through the enactment of Securities Act, 1966 had "adopted the disclosure system that required the issuer to disclose the information". In South Africa as well, in order to mitigate information asymmetry [29] states that there are ample provisions in the securities regulations to promote market transparency. Moreover, in the context of India [30] state post-liberalization, in order to mitigate information problem and to nurture the development of securities markets in India, rapid and wide-ranging legislative efforts were made. Further, [31] states that "Indian disclosure and accounting standards are as modern, updated, potent and versatile as those of any other market".

These five countries have adopted measures to strengthen their equity capital markets and to protect investors. As such, disclosure regulations are essential for maintaining the quality and integrity of markets. The present study examines the regulatory framework of the five emerging power economies, to scrutinize those regulations that mitigate information asymmetry for the smooth functioning of their equity capital markets.

\section{Methodology}

Undoubtedly, information asymmetry is a barrier in facilitating robust equity markets worldwide. While it can never get removed from equity capital markets; instead, it can only be diminished in the markets. Regulators all around the world have taken steps to reduce information problem. Scholars [1] have concluded a positive correlation between "market development" and "economic growth". BRICS countries, the emerging economies in the world, their equity markets can play a significant role in boosting their economy. Therefore, to have systematic rules and regulations for mitigating information asymmetry in equity capital markets becomes necessary. In the last two decades, strict disclosure and corporate governance laws in several countries, including the United States, India, Germany and Austria, have been enacted to decrease information asymmetry. The bottom lines of these provisions are that with the threat of legal sanctions companies issuing securities in both primary and secondary markets are bound to provide investors with complete and accurate information about the company.

\section{Research Design}

\section{Gaps Identified Existing Information Asymmetry Literature}

Several empirical studies are available assessing the effect of information asymmetry on various aspects of equity capital markets [5] [6]. However, the existing literature lacks accredits assessing analytical nuances of asymmetric 
information. By investigating those provisions that promote disclosure by borrowers of capital in the equity capital markets, thus an attempt is made to, mitigate information asymmetry.

The current study is limited to the primary equity capital markets. The primary markets are for initial public offerings and form an integral component for the companies in fulfilling their financing needs. The primary market acts as a springboard for both issuers of securities and investors. The doctrinal outline of the study is made by a systematic approach to examine the current legal framework about the reduction of asymmetric information in primary equity capital markets and how it has evolved in BRICS.

\section{Data Collection}

Sources used for information are primary and secondary. Primary sources include laws governing disclosure in BRICS countries (Table 1). Secondary sources used include online publications listed under the reference section.

In the next section, the sources listed in Table 1, examines the regulatory

Table 1. Primary sources analyzed for BRICS Nations.

\begin{tabular}{llll}
\hline Nation & Source & Related Article & Reference \\
\hline BRAZIL & 1) Law 6.385/76, known as "Securities Laws of Brazil", 1976. & Article 4, 19 & {$[32]$} \\
& 2) Law 6.404/76, known as "Corporation Law of Brazil", 1976. & Article 84 & {$[33]$} \\
& 3) CVM Instruction 400, 2003. & Article 1, 38 - 42, 52, & {$[34]$} \\
\hline
\end{tabular}

While "Securities Law" (Law 6.385/76) regulates the securities markets and establishes Brazil's regulatory authority CVM; the "Corporation Law" (Law 6.404/76) and Instruction-400 make it obligatory for companies to disclose material events, hence enforce disclosures.

\begin{tabular}{llll}
\hline RUSSIA & 4) "Russian Joint Stock Companies Law (Federal Law No. 208- FZ)", 1995. & Article 7.1 & {$[35]$} \\
& 5) "Russian Securities Market Law (Federal Law No. 39-FZ)", 1996. & Article 22, 23, 30, 51 & {$[36]$} \\
& 6) "Russian Regulation on Information Disclosure by Issuers of Securities" (No. & Appendix-2, Part B & {$[37]$} \\
454-P), 2014. & &
\end{tabular}

The laws allaying asymmetric information are "Securities Law (Federal Law No. 39-FZ)", "Joint Stock Companies Law (Federal Law No. 208FZ)" and "Regulation on Disclosure of Information by Issuers of Securities" (No. 454-P).

INDIA 7) "Securities \& Exchange Board of India, (SEBI) Issue of Capital and Disclosure Re- Schedule VIII [38] quirements) Regulations”, 2009.

8) “Indian Companies Act”, 2013.

In Indian primary equity capital markets, the "Indian Companies Act", 2013 and "SEBI (Issue of Capital and Disclosure Requirements) Regulations", 2009 reduce information asymmetry.

\begin{tabular}{llll}
\hline CHINA & 9) “Companies Law of the People’s Republic of China", 2005. & Article 86 - 87 & {$[40]$} \\
& 10) "Law of the People's Republic of China on Securities", 2005. & Article $52-54$ & {$[41]$}
\end{tabular}

In China, "Companies Law of the People's Republic of China", 2005 and "Law of the People's Republic of China on Securities", 2005 help in reducing information problem.

\begin{tabular}{llcc}
\hline SOUTH & 11 ) “South African Companies Act”, 2008. Section-100 & {$[42]$} \\
AFRICA & & & \\
\hline
\end{tabular}

In South Africa, "South African Companies Act”, 2008 curtails asymmetric information. 
framework of the five emerging power economies, to scrutinise those regulations that mitigate information asymmetry for the smooth functioning of their equity capital markets.

\section{Findings and Analysis}

Disclosure regulations are quintessential for progressing countries including BRICS [26] [28] [31] [27] [29] because primary equity capital market plays a substantial role in their companies' capital formation and in fetching investments through Foreign Institutional Investors (FIIs) and even retail investors. The risk of data asymmetry is ever present in capital markets [5], and it can exist between 1) corporate firms and investors or market analysts, 2) investment houses and financial specialists, and 3) between various commercial organisations.

Invariable risk of asymmetric information exists for any investor or analyst when evaluating companies because the companies always have information of their ebb and flow, which investors and analysts lack. Financial specialists assess organizations dependent on data they can gather from financial articulations. However, that information may be correct or may be manipulative, because of an organization's picked bookkeeping strategy, and thus, not precisely mirror the organization's real condition. Disclosure laws help in mitigating information problem and in providing market participants with a safe environment to function [23]. In the following sub-sections, this research highlights the key regulations that mitigate information asymmetry in BRICS countries.

\subsection{Brazil}

In Brazil, the law that regulates securities markets is Law 6.385 ("Securities Laws") [32]. It also provides for the setting up of its securities regulator called CVM ("Securities and Exchange Commission of Brazil"). One of the legal mandates of CVM is to provide investors access to information about the companies and the securities that they issue. CVM undertakes this responsibility under Article 4 (VI) of the "Securities Law" [32]. As per Article 19, Paragraph 5 (II) of the said Act, CVM enumerates the material to be revealed by the issuer of securities along with the application of registration [32]. This information relates to 1) general information about the issuing corporation; 2) the business it is currently doing or what it plans along-with financial and situation; 3) information related to management and principal shareholders; 4) the basic features of the issuance and in what activity the funds shall be used; 5) the vendor of the securities; and 6) the participants of the issue, their honorarium, and their association with the issuing enterprise or the vendor. CVM holds power to suspend the issuance under Article 20 if the information provided is "false or fraudulent or incorrect" [32].

The corporations in Brazil are governed by Law 6.404/76 known as "Corporation Law" which was enacted in 1976 [33]. Article 84 in particular deals with disclosures to be made by companies while going for a public issue. It stipulates that the 
companies need to coherently mention "the basis of the corporation and the motives justifying the expectation of the success of the enterprise" [33]. Further, the article states that the companies shall "specially" specify-details about the capital (total amount to be subscribed and the way it is to be paid up, authorisation of future increase if any). Next, particulars about the ratio of capital composed of a property, its details and its value as ascribed by the founders; information related to the number, types and classes of shares including their par value and their issue price; initial amount to be paid as subscription; details about the responsibilities that founders have undertaken, and contract that they have entered into and the amount that they had spent with respect to the future corporation; bylaws drafted by the company regulating prerogative issued to the founders or any third party; authorization of incorporation by the government, if required; particulars related to opening and closing of subscription period along with information related to authorized institution for initial payment; arrangement made by the corporation in case surplus results from subscription; tentative time period for conducting the general meeting of incorporation or initial meeting for assessment of the property, if required; personal details of the subscribers such as name, nationality, vocation, etc. of the founders or corporate name, head office and nationality of the corporate entity, and the numbers and the various types shares held by them; information about the financial institution working as an intermediary and keeper of relevant documents for interested party's consideration.

Another enactment to strengthen disclosure norms in Brazil was issued in 2003 by CVM called "Instruction-400" [34]. While addressing its scope, Article-1 of the instruction states that it proposes to regulate public offer of securities in both markets, primary and secondary, and aims at protecting investors through ample disclosures. While, Article-38 defines prospectus and makes its distribution compulsory by the issuer along with the underwriter for any public issue [34], under Article-39, companies have the obligation not to miss out any material fact nor induce investors by putting misleading information in the prospectus. It also specifies what goes into a prospectus-information about the offer; details of the kind of security offered, its objective and rights attached to the security; particulars about the issuer; issuing company and its financial and economic state of affairs; information about third parties, whether they have undertaken any obligation concerning the securities offered; and if they are beneficiaries of the resources funded with the offer [34]. Article- 40 articulates that the prospectus must be accompanied by documents mentioned in Appendix-III. Appendix-III sets out a proforma for a prospectus that the issuer must adhere to while drafting a prospectus for the issue [34].

\section{Disclosures Identified for Brazil}

Important disclosures [32] [33] [34], as identified include:

- Brief information about the issue: Disclosure about the operation that the company has planned, details of corporate brokers involved, recognizing the 
ideal audience, cost of the issue, and disclosure about the arrangement with the stock exchanges.

- Information about the people involved in the issue: Names, Telephone numbers and address of managers who shall give clarification related to the issue, auditors, bankers and legal consultants.

- Detailed information about the offer: This includes disclosures related to the capital structure before and after the issue; offer's Terms and Conditions; details of all contracts signed such as securities distribution contract, the contract relating to liquidity guarantee or Price stabilization; socio-economic viability of the issue. It shall also state the necessary authorizations that the company has taken from the requisite authorities, obligations of the founder post the issue, names and other details such as marital status and nationality of the founders and subscribers to the issue

- Risk Factors: The issuing corporation must disclose all risk factors associated with the investment in the light of the financial culture of the targeted audience.

- For an investor to comprehend the details relating to the financial state of the establishment, the issuer must disclose quarterly reports, last year financial statements and independent reports of the auditors and management of last three financial years.

- Information about the issuer: Information regarding the company's background; plant and property belonging to the company and disclosure related to lease agreement, if any; detailed disclosure of companies operations of the last three financial years; composition of company's capital, disclosure of any changes made during the last three financial years; disclosure of shareholder's agreements, if any; details about the members of the management board; disclosure of related party transactions, if any; disclosure related to all employees (including company's relation with the labour unions of its employees) in the last three years.

- Contingencies: Apprehension of any judicial or administrative or any other event that seems probable to the company because of its existing practices need to be stated.

- Financial information of the company not disclosed in the prospectus for which clarification can be obtained from the CVM;

- All such minutes of all Annual General Meetings or Board of Directors meetings that authorise the issuance of the issue;

- All the details of the debenture deeds, if any;

- Latest "Bylaws" of the issuing corporation; and

- Report of a specialized agency for identifying risk factors.

It also mentions the documents to be attached with the prospectus. Article-41 further states that in case of incomplete information or any other factual mistake which are essential for an investor to make an informed decision, the distribution of the prospectus shall be terminated until the necessary changes are made. Also, 
Article-42 makes it mandatory for the corporations to deliver a copy of the catalogue (prospectus) to the investors through electronic means.

\subsection{Russia}

Any joint stock company in Russia can go public under Article-7.1 of Federal Law No. 208-FZ, by altering its charter and stating that it is public [35]. Additionally, a company shall be granted to submit its commercial name declaring the public status of the legal entity, provided that their prospectus has been registered [35]. Article-22 of Federal Law No. 39-FZ provides that generally every issue of securities shall be registered by Bank of Russia (registering authority, as specified in Article-20) only if it is accompanied by a prospectus [36]. Further, Article 23 avers that every public issue of securities must be accompanied by a prospectus containing information as stipulated in Article-30 [36]. Article-30 deals with "Disclosure of Information". It defines disclosure of information as "open access to information to all stakeholders" irrespective of their intention for getting the information as long as they follow the right procedure of getting the information as laid down in their federal law.

It further provides that for joint stock companies who go public for the first time must send a prospectus for registration containing the following vital disclosures:

1) Quarterly report of the issuer: It includes a financial report of the last reported year along with the auditor's report of that particular financial report. It shall also include an Interim (financial) report for the last reported period inclusive of three months of the said year;

2) Consolidated financial reporting of the issuer;

3) Any event (including a resolution adopted in a shareholder's meeting) that may lead to an alteration in the value of securities.

The proforma for the prospectus is prescribed in "Regulation on Information Disclosure by Issuers of Securities, 2014 in Part B of its Appendix-2" [37].

\section{Disclosures Identified for Russia}

The important disclosures [35] [36] [37] include:

- Introduction: Here, the issuer needs to state the company details, brief about the categories of securities that the corporation (entity) wants to issue along with the usage of the funds obtained from the issue.

- Essential information about the bank accounts and people involved in the issue of the prospectus: The issuer must disclose his bank accounts, and information about the auditor or the audit organisation, company's advisers on the securities markets, and any other person who has signed the prospectus.

- Financial Position of the issuer: The company should give detailed characteristics of the economic activity of the entity, issuer's market capitalization, credit history and current liabilities. The issuer must further, support the financial position with the data showing its financial results, issuer's liquidity, reasonableness of capital and circulating assets, structure of issuer's capital 
and working capital, detail about issuer's strategy and expenditure on scientific and technological development, a general analysis of issuer's performance in the market, factors affecting issuer's development and issuer's competitors in the market.

- Risks: The issuer must specify in details all kinds of risks associated with the issue such as industry risks, risks related to acquisition of securities, country and regional risks, financial risks, legal risks, strategic risks, reputation risks, banking risks, risks arising out of issuer's activities, market risks, liquidity risks and operational risks.

- Detailed information about the issuer: This shall include a disclosure about the brief history of the issuer, major economic activities of the issuer, brief description of the prospects of the company, issuer's participation in its holding corporations and its subsidiaries and issuer's capital composition and details of its assets.

- Information about the management of the issuer: Here, the issuer must disclose the structure of management bodies, details of the persons constituting such bodies, their remuneration and benefits availed by them, details of persons managing the financial and economic activity of the issuer, their risk management and internal control systems. It should also include a list of employees of the issuer.

- Details about shareholders of the issuer must disclose: 1) exact number of shareholders at the time of issue; 2 ) the percentage of shareholding of members holding not less than 5 percent of shares, 3 ) the percentage of shareholding of members holding not less than 20 percent, 4) shareholding by the state or any municipal organization, 5) disclose the restrictions on the shareholders in terms of the maximum number of shares 6) voting rights and 7) transactions by shareholders who have been approved by management body and information on the receivable amount

- Financial information and accounting statements of the issuer: This shall include disclosure of annual financial statements, intermediate accounting statements, consolidated financial statements, necessary provisions of issuer's accounting policy, details of total exports and share of such exports in total sale, substantial changes accrued in last year in issuer's property and issuer's role in any litigation that may affect it economically.

- Information about securities: This shall include information about kind and form of securities, number of securities and their nominal value. The issuer must also state a total number of securities placed earlier and their owners. Further, the issuer must lay out in detail all the specific conditions and procedure for the placement of securities. Also, the manner of disclosure for the issue shall be specified. Additionally, information about Russian depository receipts shall be stated along with restrictions on acquisition and circulation of securities as imposed by Russian legislation.

- Other Information to include disclosure of any other material relating to 
the financial structure of the issuer that has not been specified (as listed above) in the prospectus. Here, the issuer shall state data on each category of issuer's shares, information about previous issues of shares, information of record-keeping entities of the rights of the issuer, declared or accrued dividends, and any other information that the issuer may deem necessary for the investor to know.

Further, Article-51 (1.1) makes the issuer of securities legally responsible for any loss suffered by any investor or security holder, in case any wrongful or misleading information is conveyed to him or stated in their prospectus.

\subsection{India}

In India, "The Capital Issues (Control) Act", 1947 governed the recent issues in equity capital markets. Post liberalisation, to be at par with securities market of other developed countries, India set up the "Securities and Exchange Board of India, (SEBI)" for disclosure is driven to prune information asymmetry [38]. SEBI's vision could be further reaffirmed by its annual report 1994-1995: "During 1994-1995, SEBI continued to take measures for improving investor protection in the primary markets through better disclosure of relevant information about the issuer and the nature of securities to be issued" [39]. The existing legal framework in India, enforcing disclosures in primary equity capital market could be categorised as 1) "Indian Companies Act", 2013 (Section-26) and 2) "SEBI (Issue of Capital and Disclosure Requirements) Regulations, 2009 (Schedule VIII)" [39].

Earlier, Indian Companies Act, 2013 (Section-26) used to contain a detailed list of provisions for the prospectus, now omitted by the Indian Companies (Amendment) Act, 2017 [39]. Section-26 articulates that every company issuing a prospectus must disclose all information and such financial reports as specified by SEBI (ICDR) Regulations, 2009 [38]. Further, Subsection-9 imposes a penalty on the company and every person associated with the issue, with fine ranging from 708 USD to 4250 USD and "imprisonment for a term which may extend to three years", in having contravened the provision of this section [39] [43].

To mitigate information asymmetry; the disclosure requirements regarding the issuance of securities are explained in detail in SEBI (ICDR) Regulations, 2009. These Regulations have revolutionised disclosure standards in India about offer documents and have brought radical changes in the functioning of public issues [39]. As per Regulation-57, "all disclosures which are true and adequate", empower applicants to make informed investment decision [39]. "ICDR Regulations (Schedule-VIII)", 2009 specifies formats for disclosures in different kinds of offerings [39].

\section{Disclosures Identified for India}

To abridge, the necessary disclosures [39] [43] to be made are as follows:

- The sequence to include a front cover page, followed by the Table of Contents, 
all definitions (including standard terms, terms related to the issue, issuer and industry, and abbreviations) and back page;

- To include separate section information on the structural risks linked to the issuer and any other risk identified by the issuer based on "materiality" and how the issuer propounds to mitigate them;

- In the introduction section, information about the issuer and all disclosures concerning the entity's [39] [43]:

- Management team members, Board of Directors, and various committees;

$\circ$ the Capital structure and the shareholding pattern (pre-issue and post-issue);

o the Security's bank account number;

$\checkmark$ the holdings of the promoter/promoter group and the employee stock option plans, if any.

- Under Specifications [39] [43] disclosures about:

○ the issue including the total request (requirement) of funds;

$\circ$ an undertaking in the offer document endorsing the organisation's provisions of finance (75 percent) through certifiable means; and

- appraisal of the project, if any, embarked on, by the issuer.

- To reveal details about the business operations and examination of issuer's entity in the offer document;

- All discussion by top management as reproduced in an entity's financial statements for the past three years;

- Any pending litigations where the "entity/promoters/promoter group/directors/ group entities" is involved. All the outstanding loans and licensing dispositions shall also be stated [43];

- Financial particulars for the last five years preceding the issue of the offer document in the offer record.

\subsection{China}

As per the "Companies Law of the People's Republic of China" [40], Article-86 states that every company must issue a prospectus before offering shares to the general public, accompanied by way of a subscription form. Further, it stipulates that the subscription form as prescribed in Article-87 such as, information related to the promoter's share subscription ("par value", "issue price" number of bearer shares issued, purpose for which money is raised from the public, rights and duties attached to the securities, start and closing dates for the offer) along with a statement that "permits subscribers to withdraw subscriptions when the shares are not fully subscribed" [40].

A combined reading of Article-1, 3 and 4 of "Law of the People's Republic of China on Securities, 2005" demonstrate that honesty and transparency are the cornerstones of their "Securities Law" [41]. Article-52 of the said Act states that every company needs to submit certain documents to the stock exchange for a listing [41]. 


\section{Disclosures Identified for China}

The important disclosures [40] [41] are:

- As per Article-53, the company to release relevant documents (after approved by stock exchange), at assigned places for public access.

- These documents include the recent prospectus of the company, audited financial statements of last three years immediately preceding the application, listing agreement, shareholder's resolution about the listing of securities, Articles of Association, business licenses, legal opinions and other documents as prescribed by the stock exchange.

- Additionally, Article-54 asserts that once a company enters into a listing agreement, it shall make known to the public the decided date on which the shares shall be floated on stock exchange, names and shareholding of top ten shareholders of the company, details about people who directly control the company and names and shareholding and bond holding of directors and senior managers of the company.

\subsection{South Africa}

Chapter 4 (Section-95 to Section-111) of the "South African Companies Act", 2008 [42] lays down provisions for "Public Offers for Companies Securities". This chapter discusses both primary and secondary securities offerings. Section-99 states that every offer of securities shall be accompanied by a prospectus. For a company to issue, the new issue of shares must comply with Section-100 which deals with "Requirements concerning Prospectus". The section states that the prospectus to reveal details "that an investor may reasonably require assessing" [42].

\section{Disclosures Identified for South Africa}

The critical disclosures [42] prescribed:

- Includes information related to the assets and liabilities of the company depicting its financial position by showing its profits and losses and cash flow statements.

- Must state the prospects of the company in which a right or interest is to be acquired. Further, it should also state the rights attached to the securities that are offered to the public.

These provisions are arduous and if any statement in the prospectus is proven to be untrue, then every Director of the establishment (at the time of issuance of prospectus), every promoter of the company or any person associated with the authorizing and issuance of the prospectus shall be responsible to pay compensation to any person who suffered loss or damage by keeping faith on the contents of the prospectus, as stated in Section-104 [42].

\subsection{Summary}

To be at par with the developed countries, BRICS have incorporated essential disclosure-related provisions in their regulatory framework. These countries 
have successfully merged the provisions with the Companies Laws of their respective jurisdictions, thereby obliging companies from their incorporation to follow the disclosure regime. As such, disclosure regulations are essential for maintaining the quality and integrity of markets. Analysing from the above, one can conclude that the disclosure regime adopted by BRICS is based on the International Standards and doctrine of materiality. However, Brazil, Russia and India have more intense disclosure requirements as compared to China and South Africa.

\section{Conclusion}

The above study is a systematic approach to examine the provisions of rules and regulation enacted by securities regulators of BRICS nations to reduce information asymmetry in their primary equity capital markets; to enhance transparency and for investors to make an informed investment decision. In turn, it supports the smooth functioning of primary equity capital markets. This research acts as an exemplification of the fact that securities regulators have taken reformative measures to mitigate information asymmetry and boosting their primary equity markets. However, this study is limited in its approach as it has not examined rules made by stock exchanges to improve transparency. Further, this research could also be extended in assessing the practical implications of such provisions in these countries.

\section{Conflicts of Interest}

The authors declare no conflicts of interest regarding the publication of this paper.

\section{References}

[1] Levine, R. (1991) Stock Markets, Growth, and Tax Policy. The Journal of Finance, 46, 1445-1465. https://doi.org/10.1111/j.1540-6261.1991.tb04625.x

[2] Marino, R. (2014) The Future BRICS: A Synergistic Economic Alliance or Business as Usual? Springer Publication, New York.

[3] Makin, A.J. and Arora, R.U. (2014) How Solid Are the BRICS? An Economic Overview. In: The Rise of the BRICS in the Global Political Economy, Edward Elgar Publishing, Cheltenham, 11-26. https://doi.org/10.4337/9781782545477.00009

[4] Akerlof, G.A. (1970) The Market for "Lemons": Quality Uncertainty and the Market Mechanism. The Quarterly Journal of Economics, 84, 488-500. https://doi.org/10.2307/1879431

[5] Leland, H.E. and Pyle, D.H. (1977) Information Asymmetries, Financial Structure and Financial Intermediation. The Journal of Finance, 32, 371-387. https://doi.org/10.1111/j.1540-6261.1977.tb03277.x

[6] Jensen, M.C. and Meckling, W.H. (1976) Theory of the Firm: Managerial Behaviour, Agency Costs and Ownership Structure. Journal of Financial Economics, 3, 305-360. https://doi.org/10.1016/0304-405X(76)90026-X

[7] Jan, D., Van Landeghem, H. and Deschoolmeester, D. (2011) Theory of the Lemon 
Markets in IS Research. In: Dwivedi, Y.K., Wade, M.R. and Schneberger, S.L., Eds., Information Systems Theory: Explaining and Predicting Our Digital Society, Springer, Berlin, Germany, 213-229. https://doi.org/10.1007/978-1-4419-6108-2_11

[8] Higson, G. (2011) Market and Market Failures. Economic Online Ltd.

[9] Kreps, D.M. (1990) A Course in Microeconomic Theory. Princeton University Press, Princeton, NJ.

[10] Healy, M.P. and Palepu, K.G. (2001) Information Asymmetry, Corporate Disclosure and the Capital Markets: A Review of the Empirical Disclosure Literature. Journal of Accounting and Economics, 31, 405-440. https://doi.org/10.1016/S0165-4101(01)00018-0

[11] Aboody, D. and Lev, B. (2000) Information Asymmetry, R\&D and Insider Gains. The Journal of Finance, 55, 2747-2766. https://doi.org/10.1111/0022-1082.00305

[12] Paredes, T. (2007) The Importance of Corporate Law: Some Thoughts on Developing Equity Markets in Developing Economies. Global Business \& Development Law Journal, 19, 401-410.

[13] Klonowski, D. (2011) Private Market in Emerging Markets: Stacking Up the BRICS. The Journal of Private Equity Summer, 14, 24-37.

[14] Rafael, L., Lopez-De-Silanes, F. and Shleifer, A. (2006) What Works in Securities Laws? Journal of Finance, 61, 1-32. https://doi.org/10.1111/j.1540-6261.2006.00828.x

[15] Frost, C.A., Gordon, E.A. and Hayes, A.F. (2006) Stock Exchange Disclosure and Market Development: An Analysis of 50 International Exchanges. Journal of Accounting Research, 44, 437-483. https://doi.org/10.1111/j.1475-679X.2006.00208.x

[16] Francis, J., LaFond, R., Olsson, P. and Schipper, K. (2005) The Market Pricing of Accruals Quality. Journal of Accounting and Economics, 39, 295-327. https://doi.org/10.1016/j.jacceco.2004.06.003

[17] Leuz, C. and Verrecchia, R.E. (2000) The Economic Consequences of Increased Disclosure. Journal of Accounting Research, 38, 91-124. https://doi.org/10.2307/2672910

[18] Lang, M. and Lundholm, R. (1993) Cross-Sectional Determinants of Analyst Ratings of Corporate Disclosures. Journal of Accounting Research, 31, 246-271. https://doi.org/10.2307/2491273

[19] Diamond. D.W. and Verrecchia, R.E. (1991) Disclosure, Liquidity and the Cost of Capital. Journal of Finance, 46, 1325-1359. https://doi.org/10.1111/j.1540-6261.1991.tb04620.x

[20] Plesco, O. and Sobol, L. (2013) The Issue of Asymmetric Information upon the Capital Market. CES Working Papers, 5, 254-266.

[21] Lakhal, F. (2008) Stock Market Liquidity and Information Asymmetry around Voluntary Earnings Disclosures: New Evidence from France. International Journal of Managerial Finance, 4, 60-75. https://doi.org/10.1108/17439130810837384

[22] Subramanyam, M. and Dasaraju, H. (2014) Corporate Governance and Disclosure Practices in Listed Information Technology (IT) Companies in India. Open Journal of Accounting, 3, 89-106. https://doi.org/10.4236/ojacct.2014.34011

[23] Farvaque, E., Refait-Alexandre, C. and Saidane, D. (2011) Corporate Disclosure: A Review of Its (Direct and Indirect) Benefits and Costs. International Economics, 128, 5-31. https://doi.org/10.1016/S2110-7017(13)60001-3

[24] Mottet, L. (2013) Cooperation and Competition among the BRICS Countries and 
Other Emerging Powers, French Centre for Research on Contemporary China. http://www.cefc.com.hk/uf/file/researchpapers/BRICS\%20report/BRICS\%20report. pdf

[25] Naganathan, V. (2013) The rise of BRICS Economy and its Impact on Global Stock Markets. International Journal of Commerce, Business and Management, 2, 67-77.

[26] Poser, N. (1967) Securities Marketing and Stock Exchanges in Black Africa. Columbia Law Review, 67, 892-925. https://doi.org/10.2307/1120968

[27] Zhang, X. (1999) The Old Problems, the New Law and the Developing Market-A Preliminary Examination of the First "Securities Law" of the People's Republic of China. The International Lawyer, 33, 983-1014.

[28] Lumelsky, G. (1997) Does Russia Need a "Securities Law”? Northwestern Journal of International Law \& Business, 18, 22-23.

[29] Chimpango, B.K. (2017) The Development of African Capital Markets: A Legal and Institutional Approach. Routledge, London. https://doi.org/10.4324/9781315408989

[30] Thomas, S. and Shah, A. (2002) The Stock Market Response to the Union Budget. Economic and Political Weekly, 37, 455-458.

[31] Fernando, A.C. (2012) Corporate Governance: Principles, Polices and Practices. Pearson Education India, Bengaluru.

[32] Securities and Exchange Commission of Brazil (CVM) (1976) Securities Laws of Brazil: Law 6.385/76.

http://www.cvm.gov.br/export/sites/cvm/subportal_ingles/menu/investors/anexos/ $\underline{\text { Law-6 }}$

[33] Securities and Exchange Commission of Brazil (CVM) (1976) Corporation Law of Brazil.

http://www.cvm.gov.br/export/sites/cvm/subportal_ingles/menu/investors/anexos/ Law-6

[34] Securities and Exchange Commission of Brazil (CVM) (2003) CVM Instruction 400.

http://www.cvm.gov.br/export/sites/cvm/subportal_ingles/menu/investors/anexos/ CVM-Instruction-400.pdf

[35] ConsultantPlus (1995) Russian Joint Stock Companies Law (Federal Law No. 208-FZ).

https://www.cbr.ru/Content/Document/File/33657/208-FZ.pdf

[36] ConsultantPlus (1996) Russian Securities Market Law (Federal Law No. 39-FZ). http://www.cbr.ru/content/document/file/36165/39-fz.pdf

[37] Central bank of Russian Federation (CBR) (2014) Russian Regulation on Information Disclosure by Issuers of Securities (No. 454-P). https://www.mrsk-ural.ru/en/disclosure/issuer/

[38] Securities and Exchange Board of India (2009) Securities \& Exchange Board of India (Issue of Capital and Disclosure Requirements) Regulations.

https://www.sebi.gov.in/legal/regulations/jun-2018/securities-and-exchange-boardof-india-issue-of-capital-and-disclosure-requirements-regulations-2009-last-amend ed-on-february-12-2018-_39242.html

[39] Ministry of Corporate Affairs (2013) Indian Companies Act. http://www.mca.gov.in/Ministry/pdf/CompaniesAct2013.pdf

[40] Ministry of Commerce of the People's Republic of China (2005) Companies Law of the People's Republic of China.

http://www.fdi.gov.cn/1800000121_39_4814_0_7.html 
[41] Ministry of Commerce of the People's Republic of China (2005) Law of the People's Republic of China on Securities.

http://www.npc.gov.cn/englishnpc/Law/2007-12/13/content_1384125.html

[42] Parliament of Republic of South Africa (2008) South African Companies Act. https://cdn.ymaws.com/www.iodsa.co.za/resource/collection/CB7E5DC1-E790-4BE D-9693-9F8AA33E0032/Companies_Act_Guide.pdf

[43] KPMG (2018) The SEBI ICDR and Listing Regulations Checklists. 1-171. https://assets.kpmg/content/dam/kpmg/in/pdf/2018/02/The-SEBI-ICDR-and-Listin g-Regulations.pdf 